\title{
Platelet-activating factor (PAF) receptor expression is associated with histopathological stage and grade and patients' survival in gastric adenocarcinoma
}

\author{
C. GIAGINIS ${ }^{1,2, *}$,E. KOUROU ${ }^{3}$, A. GIAGINI ${ }^{1}$, N. GOUTAS ${ }^{4}$, E. PATSOURIS ${ }^{1}$, G. KOURAKLIS ${ }^{3}$, S. THEOCHARIS ${ }^{1}$
}

${ }^{1}$ First Department of Pathology, Medical School, National and Kapodistrian University of Athens, Athens, Greece; ${ }^{2}$ Department of Food Science and Nutrition, University of the Aegean, Myrina, Lemnos, Greece; ${ }^{3}$ Second Department of Propedeutic Surgery, Medical School, University of Athens, Athens, Greece; ${ }^{4}$ Department of Forensic Medicine and Toxicology, Medical School, University of Athens, Athens, Greece

*Correspondence: cgiaginis@aegean.gr

Received April 26, 2013 / Accepted September 18, 2013

\begin{abstract}
Platelet activating factor (PAF) has been considered as potent inflammatory lipid mediator that exerts its actions by binding to PAF receptor (PAFR). PAF/PAFR system has been implicated in several pathophysiological states, including tumor progression, angiogenesis and metastasis. The present study aimed to evaluate the clinical significance of PAFR expression in gastric adenocarcinoma. PAFR protein expression was assessed immunohistochemically on 54 gastric adenocarcinoma tissue samples and was analyzed in relation with clinicopathological parameters, tumor proliferative capacity and patients' survival. PAFR was abundantly expressed in all gastric adenocarcinoma cases examined. Increased PAFR expression was significantly more frequently observed in well/moderately compared to poorly differentiated gastric adenocarcinoma cases $(\mathrm{p}=0.011)$. PAFR expression was significantly increased in intestinal- compared to diffuse-type cases $(\mathrm{p}=0.020)$. Elevated PAFR expression was significantly associated with smaller tumor size, absence of lymph node and organ metastasis and low tumor histopathological stage $(\mathrm{p}=0.025, \mathrm{p}<0.001, \mathrm{p}=0.009$ and $\mathrm{p}<0.001$, respectively). Additionally, patients presenting elevated PAFR expression had significantly longer survival times compared to those with low PAFR expression (log-rank test, $\mathrm{p}<0.001$ ). These results support an important potential role of PAFR signalling in gastric malignant disease progression and render further research in this field a necessity.
\end{abstract}

Key words: PAF receptor, gastric cancer, clinicopathological parameters, prognosis

Platelet-activating factor (PAF) (1-O-alkyl-2-acetyl-snglycero-3-phosphocholine) is a potent pro-inflammatory lipid mediator, presenting a very broad spectrum of biological activities [1-3]. PAF is enzymatically synthesized through two major routes, the so-called remodeling and de novo pathways, by the contribution of an acetyltransferase (PAF-AT) and is degraded by acetylhydrolases (PAF-AH) into its biologically inactive form, lyso-PAF $[4,5]$. PAF is secreted by many different cell types, including endothelial, stromal and inflammatory cells, as well as platelets and keratinocytes $[4,5]$. Notably, it has also been described to be produced by many different tumor cells [6-8]. PAF exerts its functions by binding to a membrane-associated receptor in responsive cells termed to as PAF receptor (PAFR) $[4,5]$. PAFR is a specific seven transmembrane-spanning G-protein-coupled receptor expressed in several cell types, such as endothelial and inflammatory cells, as well as in tumor cells $[5,8]$. The PAFR gene produces three different mRNA species (transcript 1, transcript 2 and an elongated form of the transcript 2); both transcripts ultimately yield the functional PAFR [9]. PAFR can transduce pleiotropic functions such as cell motility, smooth muscle contraction, synthesis and release of mediators and cytokines [5, 8]. Upon PAF/PAFR activation, the signal transducers and activators of transcription (STAT) pathways are activated by phosphorylation changes, dimerization, and translocated into the nucleus to activate transcription of specific genes in regulation of cellular functions [10,11].

Gastric cancer is the second largest cause of cancer-related death worldwide, presenting the higher incidence in Japan and China, lower in Europe and the lowest in the USA [12, 13]. Studies on gastric cancer development suggest that ge- 
netic predisposition, infection, and diet are parts of a complex interaction [13, 14]. Helicobacter pylori (HP) infection and to a lesser extent smoking have been identified as the main environmental risk factors for gastric cancer $[13,14]$. Chronic inflammation plays important roles in the development of various cancers of the digestive tract, including HP-associated gastric cancer [15]. Notably, several inflammatory mediators have been associated with tumor progression, angiogenesis and metastasis in gastric cancer [16, 17]. The molecular mechanisms by which chronic inflammation is linked to tumor progression include increased pro-inflammatory mediators' production, such as cytokines, chemokines, reactive oxygen intermediates, cyclo-oxygenase-2 (COX-2), 5-lipoxygenase, (5-LOX), phospholipase-A2 (PL-A2), matrix metalloproteinases (MMPs), and lipid second messengers, which are orchestrated by transcription factors, such as nuclear factor- $\kappa \mathrm{B}$ (NF- $\kappa \mathrm{B})$, STAT3, activator protein-1 (AP-1) and hypoxia-inducible factor-1 $\alpha$ (HIF-1 $\alpha)$ [18].

Subsequent research has suggested that PAF/PAFR pathway is implicated in a variety of inflammatory pathophysiological situations, including allergic reaction, cardiovascular and neuronal function, reproduction, ischemia-reperfusion organ injury, sepsis and shock $[3,19$ 21]. Notably, PAF by binding to PAFR has been considered to activate several pathways which may result in the onset and development of tumor induced angiogenesis and metastasis $[22,23]$. In vitro and animal studies suggest that PAF can act on the growth of various human tumor cell lines, increasing adhesiveness of tumor cells to vascular endothelia, enhancing oncogene expression and contributing to tumor development through enhancement of cell motility and stimulation of angiogenic response [24-29]. PAF has been reported to mediate the effects of vascular endothelial growth factor (VEGF) and basic fibroblast growth factor (bFGF), which play crucial roles during tumor angiogenesis process $[30,31]$. PAF has also been associated with early malignant transformation in BRCA1-mutant epithelial ovarian cells [32]. Moreover, melanocytic tumorigenesis was evident in transgenic mice expressing high levels of PAFR [33]. Intratumoral PAF production was shown to be ascribed to both tumor cells and those of the microenvironment, including infiltrating macrophages, supporting evidence that PAF may be responsible for potentiating tumor growth, neoangiogenesis, and cell motility $[25,34]$. In humans, the contribution of PAF/PAFR pathway is mainly suspected in lung, breast, ovarian, colorectal, hepatocellular and thyroid carcinoma, as also in melanoma [29, 35-43]. Importantly, it has been suggested that inhibiting PAF/PAFR pathway at the level of a ligand or receptor may result in an effective inhibition of experimental tumor growth and metastasis [22, 23].

In view of above considerations, the present study aimed to assess immunohistochemically PAFR expression in 54 gastric adenocarcinoma patients, in association with clinicopathological parameters, tumor proliferative capacity and patients' survival.

\section{Patients and methods}

Patients. Fifty-four gastric tumor samples obtained from an equal number of patients who underwent surgical resection due to gastric cancer at the $2^{\text {nd }}$ Department of Propedeutic Surgery, Medical School, University of Athens, were consecutively included in this study. None of the patients had received chemotherapy or radiation before surgery. Forty-three (79.6\%) of the patients were men and $11(20.4 \%)$ were women. The mean age of the patient cohort was $67.45 \pm 8.43$ years (median: 67 years, range: $39-88$ years). Tumors were typed according to Lauren classification as intestinal in $25(46.3 \%)$ and diffuse in $29(53.7 \%)$ gastric adenocarcinoma cases [44]. Three levels of differentiation were used to classify grading as: well differentiated in $1(1.9 \%)$, moderately in $25(46.3 \%)$ and poorly differentiated in 28 (51.9\%) patients. Tumors staging was assessed using the $5^{\text {th }}$ edition of the Tumor, Node, Metastasis (TNM) system according to the Union Internationale Contra la Cancrum (UICC) and the American Joint Committee on Cancer (AJCC) [45]. The resected tumors were staged as: T1 in $6(11.1 \%)$; T2 in $16(19.6 \%)$; T3 in $26(48.1 \%)$ and T4 in $6(11.1 \%)$ cases. Twenty (37.0\%) patients were lymph node negative (N0), and 34 (63.0\%) lymph node positive; N1 in 32 (59.3\%) and N2 in $2(3.7 \%)$ cases. Seven (13.0\%) patients presented organ metastasis. Patients were followed up for a time interval between 1 to 148 months $(52.01 \pm 44.70$ months). Thirty-seven (68.5\%) patients were dead at the time of the last follow up.

Immunohistochemistry. Immunostaining for PAFR was performed on paraffin-embedded tissue sections using the commercially available goat anti-human PAFR as primary antibody (N-17, sc-8741, Santa Cruz Biotechnology, CA, USA). In brief, formalin-fixed paraffin-embedded tissue sections of $4 \mu \mathrm{m}$ thickness were dewaxed in xylene and were brought to water through graded alcohols. To remove the endogenous peroxidase activity, sections were treated with freshly prepared $0.3 \%$ hydrogen peroxide in methanol in the dark, for $30 \mathrm{~min}$, at room temperature. Non-specific antibody binding was then blocked using a specific blocking reagent for goat primary antibodies (Eraser, Biocare Medical, Walnut, Creek, CA, USA) for $8 \mathrm{~min}$. The sections were incubated for 1 hour, at room temperature, with the primary antibody diluted at a concentration 1:100 in phosphate buffered saline (PBS). After washing three times with PBS, sections were incubated for 30 minutes at room temperature with biotinylated linking reagent donkey, anti-goat immunoglobulins diluted 1:150 in PBS (Santa Cruz Biochemicals, Santa Cruz, CA, USA), and rinsed three times with PBS. The sections were then incubated with peroxidase-conjugated streptavidin label (Dakopatts, Glostrup, Denmark), for 20 minutes. The resultant immune peroxidase activity was developed in $0.5 \% 3,3^{\prime}$-diaminobenzidine hydrochloride (DAB; Sigma, Saint Louis, MO, USA) in PBS containing $0.03 \%$ hydrogen peroxide for $3 \mathrm{~min}$. Sections were counterstained with Harris' hematoxylin and mounted in Entellan (Merck, Darmstadt, Germany). Appropriate negative 

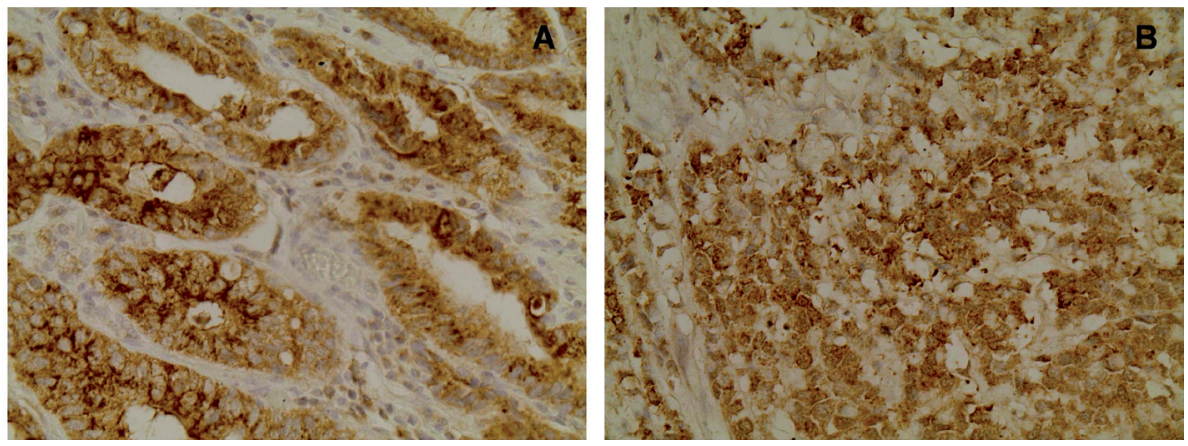

Figure 1. Representative immunostainings for PAFR expression in tumor cells of gastric adenocarcinoma. Streptavidin-biotin-peroxidase, DAB chromogen, Harris hematoxylin counterstain (original magnification X400). A. Intestinal-type B. Diffuse-type.

controls were performed by omitting the primary antibody and/or substituting it with an irrelevant anti-serum. As positive controls, paraffin-embedded colon cancer sections with known increased PAFR immunoreactivity were used. The tumors' proliferative capacity was assessed immunohistochemically, using a mouse anti-human Ki-67 antigen; $\operatorname{IgG}_{1 \mathrm{k}}$ antibody (clone MIB-1, Dakopatts), as previously described [46-48].

Evaluation of immunohistochemistry. Immunohistochemical evaluation was performed by counting at least 1000 tumor cells in each case by two independent observers (S.T. and N.G.) blinded to the clinical data, with complete observer agreement. The immunoreactivity of the tumor cells for PAFR was scored according to the percentage of PAFR positive tumor cells as 0 : negative staining- $0-4 \%$ of tumor cells positive; $1: 5$ $24 \%$ of tumor cells positive; $2: 25-49 \%$ of tumor cells positive; 3: $50-74 \%$ of tumor cells positive; $4: 75-100 \%$ of tumor cells positive and according to its intensity as 0 : negative staining, 1: mild staining; 2: intermediate staining; 3: intense staining. Finally, the expression of PAFR was classified as low; if the total score was $\leq 5$ and high; if the total score was $\geq 6$. In this way, we ensure that each group has a sufficient and more homogeneous number of cases in order to be comparable with the other groups [46-48].

Statistical analysis. Chi-square test was used to assess the associations of PAFR protein expression with clinicopathological variables. Survival curves were constructed using the Kaplan-Meier method and the differences between the curves were compared by the log rank test. A Cox proportional-hazard regression model was developed to evaluate the association between the potential prognostic marker and patients' survival. Cox regression analysis was conducted at both univariate and multivariate levels. A p-value less than 0.05 was considered the limit of statistical significance. SPSS for Windows Software was used for all analyses (SPSS Inc., 2003, Chicago, USA).

\section{Results}

PAFR was abundantly expressed in gastric adenocarcinoma cases examined, presenting mainly a cytoplasmic and occasionally membraneous pattern of staining (Figure 1). All cases were found positive for PAFR, while the mean percentage PAFR expression value was $52.6 \%$. The intensity of PAFR

Table 1. Associations of PAFR expression with clinicopathological variables in 54 patients with gastric adenocarcinoma

\begin{tabular}{|c|c|c|c|}
\hline \multirow{2}{*}{$\begin{array}{l}\text { Clinicopathological } \\
\text { variables }\end{array}$} & \multicolumn{2}{|c|}{ PAFR expression } & \multirow[b]{2}{*}{ p-value } \\
\hline & Low (\%) & High (\%) & \\
\hline Patients $(n=54)$ & $22(40.7)$ & $32(59.3)$ & \\
\hline Age & & & 0.651 \\
\hline$<67.45$ yrs & $11(20.4)$ & $18(33.3)$ & \\
\hline$\geq 67.45$ & $11(20.4)$ & $14(25.9)$ & \\
\hline Gender & & & 0.721 \\
\hline Men & $17(31.5)$ & $26(48.1)$ & \\
\hline Women & $5(9.3)$ & $6(11.1)$ & \\
\hline Histopathological type & & & 0.020 \\
\hline Intestinal & $6(11.1)$ & $19(35.2)$ & \\
\hline Diffuse & $16(29.6)$ & $13(24.1)$ & \\
\hline Histopathological grade & & & 0.011 \\
\hline $\begin{array}{l}\text { Well + Moderately } \\
\text { differentiated }\end{array}$ & $6(11.1)$ & $20(37.0)$ & \\
\hline Poorly differentiated & $16(29.6)$ & $12(22.2)$ & \\
\hline pT classification & & & 0.025 \\
\hline $\mathrm{T} 1-2$ & $5(9.3)$ & $17(31.5)$ & \\
\hline $\mathrm{T} 3-4$ & $17(31.5)$ & $15(27.8)$ & \\
\hline pN classification & & & $<0.001$ \\
\hline No & $2(3.7)$ & $18(33.3)$ & \\
\hline N1-2 & $20(37.0)$ & $14(25.9)$ & \\
\hline pM classification & & & 0.009 \\
\hline M0 & $16(29.6)$ & $31(57.4)$ & \\
\hline M1 & $6(11.1)$ & $1(1.9)$ & \\
\hline pStage & & & $<0.001$ \\
\hline I-II & $4(7.4)$ & $24(44.4)$ & \\
\hline III-IV & $18(33.3)$ & $8(14.8)$ & \\
\hline Ki-67 protein statement & & & 0.918 \\
\hline Below mean value & $10(18.5)$ & $15(27.8)$ & \\
\hline Over mean value & $12(22.2)$ & $17(31.5)$ & \\
\hline
\end{tabular}



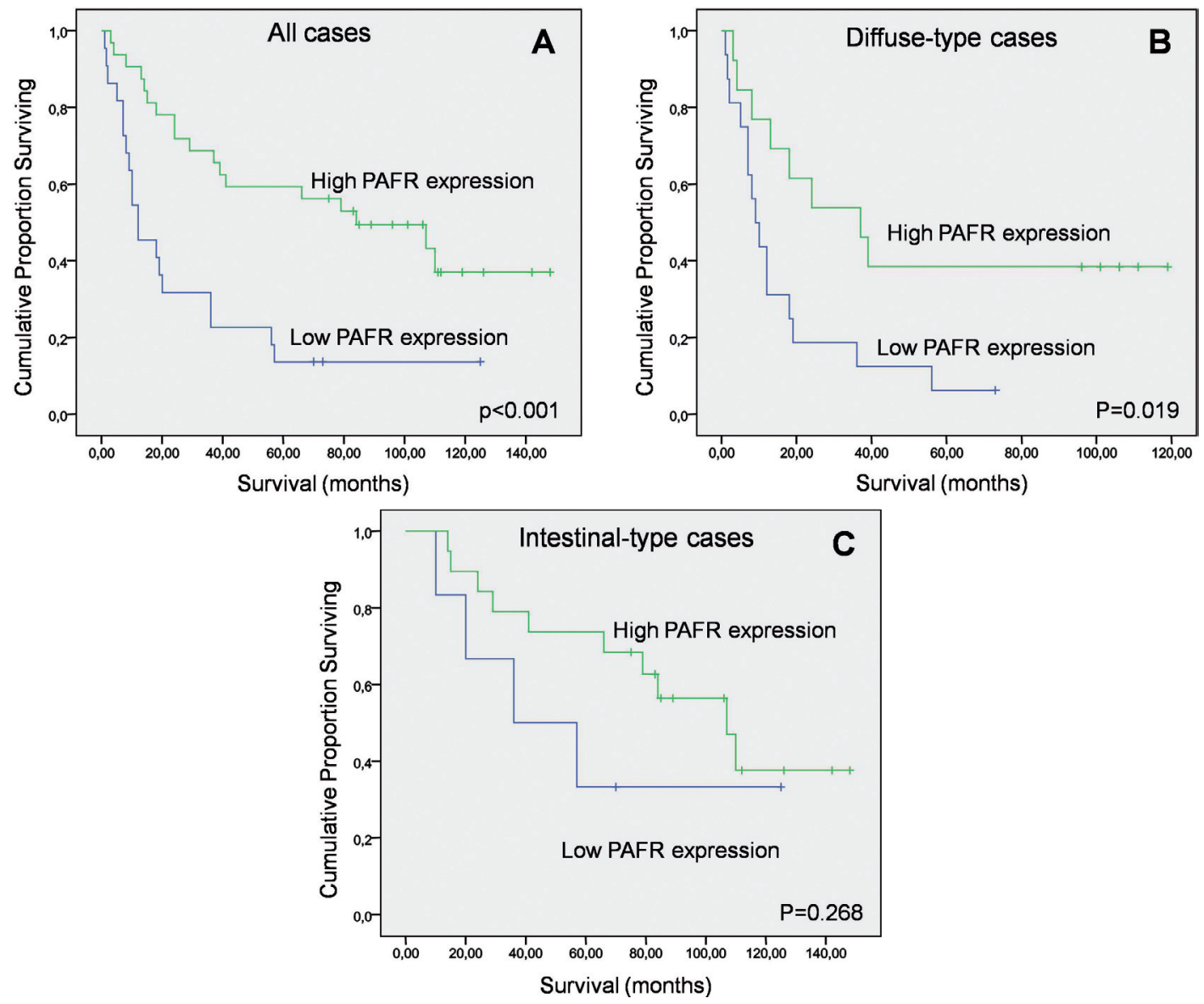

Figure 2. Kaplan-Meier survival analysis stratified according to PAFR expression in A. All gastric cancer cases, B. Diffuse-type gastric cancer cases and C. Intestinal-type gastric cancer cases

immunostaining was classified as mild in 15 (27.8\%), moderate in $25(46.3 \%)$ and intense in $14(25.9 \%)$ out of 54 gastric adenocarcinoma cases. By applying the immunohistochemical score, $22(40.7 \%)$ cases were found to present low PAFR expression and the remaining $32(59.3 \%)$ out of 54 gastric adenocarcinoma cases showed high PAFR expression. All the gastritis cases $(n=6)$ showed low PAFR expression.

In cross-tables, PAFR expression was associated with tumor histopathological type as intestinal-type gastric adenocarcinoma cases showed a significantly increased incidence of high PAFR expression compared to diffuse-type ones (Table $1, \mathrm{p}=0.020)$. High PAFR expression was significantly more frequently observed in well/moderately differentiated compared to poorly differentiated gastric adenocarcinoma cases (Table 1, p=0.011). High PAFR expression was significantly associated with smaller tumor size, absence of lymph node and organ metastasis and low tumor histopathological stage (Table 1, $\mathrm{p}=0.025, \mathrm{p}<0.001, \mathrm{p}=0.009$ and $\mathrm{p}<0.001$, respectively). PAFR expression did not show any association with patients' age and gender and tumor proliferative capacity assessed by Ki-67 protein statement (Table $1,>0.05$ ).
Kaplan-Meier survival analysis was performed to assess the strength of the association of each clinicopathological parameter and PAFR expression (low vs high) with overall patients' survival. Patients' age, histopathological type, grade and stage, tumor size, lymph node and organ metastases and PAFR expression were identified as significant prognostic factors of patients' survival (Table 2, $\mathrm{p}=0.025, \mathrm{p}=0.002$, $\mathrm{p}<0.001, \mathrm{p}<0.001, \mathrm{p}=0.023, \mathrm{p}=0.007, \mathrm{p}=0.009$ and $\mathrm{p}<0.001$, respectively). Kaplan-Meier survival curves indicated that patients with high PAFR expressing tumors had significantly longer survival times compared to patients with low PAFR expression (Figure2A, log-rank test, $\mathrm{p}<0.001$ ). The mean survival time in patients presenting high PAFR expression was 84.30 months (95\% CI: 63.94-104.66 months), whereas in those presenting low PAFR expression was 31.89 months (95\%: 15.14-48.63 months). In multivariate analysis, patients' age and tumor histopathological grade, but not PAFR expression, tumor histopathlogical type and stage, were identified as independent prognostic factors of patients' survival (Table 3, Cox regression analysis, $\mathrm{p}=0.008, \mathrm{p}=0.003, \mathrm{p}=0.065, \mathrm{p}=0.820$ and $\mathrm{p}=0.223$, respectively). 
Table 2. Kaplan-Meier survival analysis of PAFR expression and clinicopathological variabes

\begin{tabular}{|c|c|c|c|c|c|c|}
\hline $\begin{array}{l}\text { Clinicopathological } \\
\text { Variables }\end{array}$ & & Cases & Events & $\begin{array}{l}\text { Mean Survival } \\
\text { (months) }\end{array}$ & Standard Error & $P, \log$-rank test \\
\hline \multirow[t]{2}{*}{ Age (years) } & $<67.45$ & 29 & 17 & 80.12 & 11.13 & 0.025 \\
\hline & $\geq 67.45$ & 25 & 20 & 44.29 & 10.22 & \\
\hline \multirow[t]{2}{*}{ Gender } & Male & 43 & 28 & 68.18 & 9.30 & 0.380 \\
\hline & Female & 11 & 9 & 41.18 & 11.52 & \\
\hline \multirow[t]{2}{*}{ Histopathological type } & Intestinal & 25 & 14 & 89.19 & 10.87 & 0.002 \\
\hline & Diffuse & 29 & 23 & 36.67 & 8.14 & \\
\hline \multirow[t]{2}{*}{ Histopathological grade } & Well+Moderately & 26 & 12 & 100.52 & 10.45 & $<0.001$ \\
\hline & Poorly & 28 & 25 & 26.33 & 5.99 & \\
\hline \multirow[t]{2}{*}{ pT classification } & $\mathrm{T} 1-2$ & 22 & 12 & 85.93 & 12.36 & 0.023 \\
\hline & $\mathrm{T} 3-4$ & 32 & 25 & 47.42 & 9.45 & \\
\hline \multirow[t]{2}{*}{ pN classification } & No & 20 & 10 & 93.77 & 13.06 & 0.007 \\
\hline & N1-2 & 34 & 27 & 43.02 & 7.74 & \\
\hline \multirow[t]{2}{*}{ pM classification } & M0 & 47 & 31 & 69.16 & 8.65 & 0.009 \\
\hline & M1 & 7 & 6 & 19.42 & 9.23 & \\
\hline \multirow[t]{2}{*}{ pStage } & $\mathrm{I}+\mathrm{II}$ & 28 & 15 & 89.04 & 10.49 & $<0.001$ \\
\hline & $\mathrm{III}+\mathrm{IV}$ & 26 & 22 & 34.73 & 9.34 & \\
\hline \multirow[t]{2}{*}{ PAFR expression } & Low & 22 & 19 & 31.89 & 8.54 & $<0.001$ \\
\hline & High & 32 & 18 & 84.30 & 10.38 & \\
\hline
\end{tabular}

Statistical analysis was further performed in each gastric adenocarcinoma histopathological type, separately. In diffuse-type gastric adenocarcinoma, PAFR expression was significantly associated with histopathological stage $(\mathrm{p}=0.017)$ and borderline with lymph node metastases $(\mathrm{p}=0.051)$. Kaplan-Meier survival curves indicated that diffuse-type gastric adenocarcinoma patients with high PAFR expression presented significantly longer survival times compared to those with low PAFR expression (Figure 2B, log-rank test, $\mathrm{p}=$ 0.019), whereas PAFR expression did not remain significant in multivariate analysis (Cox regression analysis, $\mathrm{p}=0.405$ ). In intestinal-type gastric adenocarcinoma, PAFR expression was significantly associated with histopathological stage $(\mathrm{p}=0.005)$ and lymph node metastases $(\mathrm{p}=0.007)$ and borderline with organ metastases $(p=0.069)$. Intestinal-type gastric adenocarcinoma patients presenting high PAFR expression showed longer survival times compared to those with low PAFR expression at a no significant level though (Figure 2C, log-rank test, $\mathrm{p}=0.268$ ).

\section{Discussion}

PAF/PAFR pathway has been implicated in several pathophysiological situations, including tumor progression, angiogenesis and metastasis. However, most of the existing data so far has been derived from in vitro studies and animal models, whereas only a few clinical studies had focussed on the assessment of PAFR expression levels in human malignancies [29, 35-43]. Moreover, there is neither experimental nor clinical evidence so far concerning the implication of PAF/PAFR pathway in the development and progression of gastric neoplasia.
Table 3: Multivariate survival analysis for patients' age, histopathological grade, stage and type and PAFR expression

\begin{tabular}{lcc}
\hline $\begin{array}{l}\text { Clinicopathological } \\
\text { Variables }\end{array}$ & HR $(\mathbf{9 5 \%} \mathrm{CI})$ & p-value \\
\hline $\begin{array}{l}\text { Age } \\
\text { (<67.45 / } \geq 67.45 \text { yrs })\end{array}$ & $0.385(0.190-0.778)$ & 0.008 \\
$\begin{array}{l}\text { Histopathological type } \\
\text { (Intestinal / Diffuse) }\end{array}$ & $0.906(0.389-2.114)$ & 0.820 \\
$\begin{array}{l}\text { Histopathological grade } \\
\text { (Well+Moderately / Poorly) }\end{array}$ & $0.222(0.083-0.591)$ & 0.003 \\
$\begin{array}{l}\text { pStage } \\
\text { (I+II / III+IV) }\end{array}$ & $0.601(0.265-1.362)$ & 0.223 \\
$\begin{array}{l}\text { PAFR expression } \\
\text { (Low / High) }\end{array}$ & $2.131(0.954-4.762)$ & 0.065 \\
\hline
\end{tabular}

HR: Hazard Ratio; CI: Confidence Intervals

In this aspect, the present study supported, for the first time, evidence that PAFR may participate in gastric cancer progression. In fact, we found that PAFR was abundantly expressed in all gastric adenocarcinoma cases examined. Moreover, elevated PAFR expression was significantly associated with higher tumor differentiation and decreased disease stage, smaller tumor size, absence of lymph node and organ distance metastases and longer patients' survival times. Additionally, in intestinal-type gastric adenocarcinoma cases significantly increased PAFR expression compared to diffuse-type ones was noted. Weak PAFR expression was also noted in epithelial cells in 6 cases of gastritis [Giaginis et al, unpublished data]. In accordance with our findings, an immunohistochemical study conducted on 60 hepatocellular carcinoma patients revealed significant association between low PAFR expression and poor tumor 
differentiation, portal vein invasion and poor patients' posthepatectomy survival [41]. Moreover, this study indicated that multiple recurrences and distant metastases were more often observed in patients presenting low compared to those with high PAFR expression [41]. Another immunohistochemical study revealed that PAFR expression was significantly increased in ovarian cancer patients compared to benign ovarian tissue specimens, being varied across different histological subtypes of the ovarian cancer [40]. In fact, enhanced PAFR expression was significantly more frequently observed in clear cell, serous invasive and endometrioid types compared to mucinous and benign ovarian tumors [40]. Furthermore, that study supported evidence that PAF/PAFR may play a significant role in ovarian cancer progression and invasion through activation of EGFR/Src/FAK/Paxillin pathway [40].

Apart from the gradually increasing research in several human malignancies, there are only a few clinical studies so far investigating PAF/PAFR pathway in tumor development and progression. These clinical studies have suggested that PAFR transcripts levels were unaltered in colorectal, lung and thyroid carcinoma [36-38], whereas PAFR transcript-2 (tissue-type) levels were increased in liver metastasis of colorectal cancer [49]. Moreover, both PAFR transcript-1 (leukocyte-type) and -2 (tissue-type) levels were found to be elevated in hepatocellular carcinoma compared to non-tumor tissues [42]. PAFR transcripts were also detected in human meningiomas; however, their levels were not correlated with tumor grade, mitotic index, presence of necrosis, as well as intensity of the neovascularization and chronic inflammatory response [50]. PAF-R transcripts, PAF, the lyso-PAF precursor and the enzymatic activities implicated in lyso-PAF formation (i.e. phospholipase A2-PLA2) and PAF degradation (PAF-AHA) were also detected in the human thyroid gland [38]. However, their levels were similar in normal thyroid tissue and in hyperplastic goitre, benign adenoma and papillary carcinoma. Additionally, in thyroid malignancy, non associations with patients' TNM status and histological subtype of papillary thyroid carcinoma were noted [38].

Furthermore, plasma PAF-PLA2 and -AHA were significantly increased in colorectal cancer patients compared to healthy controls [37]. Notably, tissue concentrations of PLA2, lyso-PAF, PAF and AHA were inversely correlated with Dukes' stage in colorectal carcinoma patients [37]. Montrucchio et al. also reported that PAF levels in the lipid extracts of breast carcinoma patients were significantly increased compared to healthy controls [29]. The increased PAF levels in breast tumors were associated with high microvessel density, supporting evidence for a potential participation of PAF in the breast cancer neovascularization process [29]. Nigman et al. further indicated that plasma PAF levels were significantly increased in malignant compared to benign breast tumors and normal tissue [51]. In another study, PAF was detected in almost all human breast carcinoma cases examined, whereas it was undetectable in most of the matched, nontumoral breast tissue samples [39]. Notably, intratumor PAF levels were el- evated when axillary lymph node involvement was low, while increased axillary extension (two or more positive lymph nodes) was associated with a decreased intratumor PAF level [39]. On the other hand, no significant differences between blood PAF amounts of lung cancer patients and a control group of patients with chronic obstructive pulmonary disease induced by habitual smoking were reported [36]. Moreover, serum PAF-AHA levels were not different between lung cancer patients and control group, whereas PAF levels were markedly reduced in the lung tumor tissues as compared to the non-tumor tissues [36]. In this aspect, it should be noted, that the existing limitations on the assessment of PAF activity may render the current data not adequate in order for precise conclusions to be drawn.

Recent data has also suggested that inhibiting PAF/PAFR pathway at the level of a ligand or receptor may result in an effective inhibition of experimental tumor growth and metastasis [22, 23]. Importantly, specific PAFR antagonists have been considered to exert a potential effect in blocking protective tumor responses and potentiating chemotherapy $[52,53]$. In this aspect, recent experiments have shown an important role of PAF in chemotherapy, demonstrating that PAFR activation can augment cytokine production induced by chemotherapy through a NF- $\kappa$ B dependent mechanism [54]. PAFR activation was also reported to induce upregulation of antiapoptotic gene products, such as Bcl-2, thus attenuating the cytotoxic effect of chemotherapeutic agents [55]. Animals co-treated with cisplatin and the PAFR antagonist, WEB2086, presented significantly decreased tumor growth compared to the control group and those treated with only one agent, supporting evidence that PAFR accumulation and signalling may be part of a prosurvival program of melanoma cells [43]. In Ehrlich Ascitis Tumor (EAT) and B16F10 melanoma, PAFR-dependent pathways were activated during experimental tumor growth, modifying the microenvironment and the phenotype of the tumor macrophages, supporting evidence that combination therapy with a PAFR antagonist and a chemotherapeutic drug may represent a new and promising strategy for the treatment of some tumors [56].

\section{Conclusions}

The present study supported for the first time clinical evidence that PAFR was abundantly expressed in human gastric adenocarcinoma. PAFR expression was associated with clinicopathological parameters crucial for patients' management and prognosis. Of even more clinical significance are the data supporting the potential role of PAFR in the pathophysiological aspects of the disease that affect patients' survival. These findings suggest an important potential role of PAFR in the biological mechanisms underlying the carcinogenic evolution of gastric adenocarcinoma. Further research conducted on larger cohorts and focused on each histopathological type separately that additionally concern more sensitive techniques is strongly recommended. 


\section{References}

[1] DEMOPOULOS CA, PINCKARD RN, HANAHAN DJ. Platelet activating factor. Evidence for 1-O-alkyl-2-acetyl-sn-glyceryl3 -phosphorylcholine as the active component (a new class of lipid chemical mediators). J Biol Chem 1979; 254: 9355-9358.

[2] PINCKARD RN, MCMANUS LM, DEMOPOULOS CA, HALONEN M, CLARK PO et al. Molecular pathobiology of acetyl glyceryl ether phosphorylcholine: evidence for the structural and functional identity with plateletactivating factor. J Reticuloendothel Soc 1980; 28: 95-103.

[3] YOST CC, WEYRICH AS, ZIMMERMAN GA. The platelet activating factor (PAF) signaling cascade in systemic inflammatory responses. Biochimie 2010; 92: 692-697. http: //dx.doi. org/10.1016/j.biochi.2010.02.011

[4] PRESCOTT SM, ZIMMERMAN GA, MCINTYRE TM. Platelet-activating factor. J Biol Chemi 1990; 265: 17381-17384.

[5] MELNIKOVA VO, VILLARES GJ, BAR-ELI M. Emerging roles of PAR-1 and PAFR in melanoma metastasis. Cancer Microenviron 2008; 1: 103-111. http: //dx.doi.org/10.1007/ s12307-008-0002-7

[6] Camussi G, Montrucchio G, Lupia E, Soldi R, COMOGLIO $\mathrm{PM}$ et al. Angiogenesis induced in vivo by hepatocyte growth factor is mediated by platelet-activating factor synthesis from macrophages. J Immunol 1997; 158: 1302-1309.

[7] LI T, SOUTHALL MD, YI Q, PEI Y, LEWIS D et al. The epidermal platelet activating factor receptor augments chemotherapy-induced apoptosis in human carcinoma cell lines. J Biol Chem 2003; 278: 16614-16621. http: //dx.doi. org/10.1074/jbc.M211287200

[8] BRAEUER RR, ZIGLER M, VILLARES GJ, DOBROFF AS, BAR-ELI M. Transcriptional control of melanoma metastasis: the importance of the tumor microenvironment. Semin Cancer Biol 2011;21: 83-88. http: //dx.doi.org/10.1016/ j.semcancer.2010.12.007

[9] IZUMI T, SHIMIZU T. Platelet-activating factor receptor: gene expression and signal transduction. Biochim Biophys Acta 1995; 1259: 317-333 http: //dx.doi.org/10.1016/00052760(95)00171-9

[10] LUKASHOVA V, ASSELIN C, KROLEWSKI JJ, ROLAPLESZCZYNSKI M, STANKOVA J. Gprotein- independent activation of Tyk2 by the platelet-activating factor receptor. J Biol Chem 2001; 276: 24113-24121. http: //dx.doi. org/10.1074/jbc.M100720200

[11] WENTA N, STRAUSS H, MEYER S, VINKEMEIER U. Tyrosine phosphorylation regulates the partitioning of STAT1 between different dimmer conformations. Proc Natl Acad Sci USA 2008; 105: 9238-9243. http: //dx.doi.org/10.1073/ pnas.0802130105

[12] HE QY, CHEUNG YH, LEUNG SY, YUEN ST, CHU KM et al. Diverse proteomic alteration in gastric adenocarcinoma. Proteomics 2004; 4: 3276-3287. http: //dx.doi.org/10.1002/ pmic. 200300916

[13] FORMAN D, BARLEY VJ. Gastric cancer: global pattern of the disease and an overview of environmental risk factors. Best Practice Res Clin Gastroenterol 2006; 20: 633-649. http: //dx.doi.org/10.1016/j.bpg.2006.04.008
[14] HOHENBERGER P, GRETSCHEL S. Gastric cancer. Lancet 2003; 362: 305-315. http: //dx.doi.org/10.1016/S01406736(03)13975-X

[15] CHIBA T, MARUSAWA H, USHIJIMA T. Inflammation-associated cancer development in digestive organs: mechanisms and roles for genetic and epigenetic modulation. Gastroenterol 2012; 143: 550-563. http: //dx.doi.org/10.1053/j.gastro.2012.07.009

[16] ZABALETA J. Multifactorial etiology of gastric cancer. Methods Mol Biol. 2012; 863: 411-435. http: //dx.doi. org/10.1007/978-1-61779-612-8 26

[17] Tsujimoto H, Ono S, Ichikura T, Matsumoto Y, Yamamoto $\mathrm{J}$ et al. Roles of inflammatory cytokines in the progression of gastric cancer: friends or foes? Gastric Cancer 2010; 13: 212-221. http: //dx.doi.org/10.1007/s10120-010-0568-x

[18] VENDRAMINI-COSTA DB, CARVALHO JE. Molecular link mechanisms between inflammation and cancer. Curr Pharm Des 2012; 18: 3831-3852 http: //dx.doi.org/10.2174/ 138161212802083707

[19] HONDA Z-I, ISHII S, SHIMIZU T. Platelet-activating factor receptor. J Biochem 2002; 131: 773-779. http: //dx.doi. org/10.1093/oxfordjournals.jbchem.a003164

[20] TIEMANN U. The role of platelet-activating factor in the mammalian female reproductive tract. Reprod Domest Anim. 2008; 43: 647-655. http: //dx.doi.org/10.1111/j.14390531.2007.00959.x

[21] EDWARDS LJ, CONSTANTINESCU CS. Platelet activating factor/platelet activating factor receptor pathway as a potential therapeutic target in autoimmune diseases. Inflamm Allergy Drug Targets 2009; 8: 182-190. http: //dx.doi.org/10.2174/ $\underline{187152809788681010}$

[22] MELNIKOVA V, BAR-ELI M. Inflammation and melanoma growth and metastasis: the role of platelet-activating factor (PAF) and its receptor. Cancer Metastasis Rev 2007; 26: 359-371. http: //dx.doi.org/10.1007/s10555-007-9092-9

[23] TSOUPRAS AB, IATROU C, FRANGIA C, DEMOPOULOS $\mathrm{CA}$. The implication of platelet activating factor in cancer growth and metastasis: potent beneficial role of PAF-inhibitors and antioxidants. Infect Disord Drug Targets 2009; 9: 390-399. http: //dx.doi.org/10.2174/187152609788922555

[24] Maggi M, Bonaccorsi L, Finetti G, Carloni V, Muratori M et al. Platelet-activating factor mediates an autocrine proliferative loop in endometrial adenocarcinoma cell line HEC-1A. Cancer Res. 1994; 54: 4777-4784.

[25] BUSSOLATI B, BIANCONE L, CASSONI P, RUSSO S, ROLAPLESZCZYNSKI $M$ et al. PAF produced by human breast cancer cells promotes migration and proliferation of tumor cells and neo-angiogenesis. Am J Pathol 2000; 157: 1713-1725. http: //dx.doi.org/10.1016/S0002-9440(10)64808-0

[26] MANNORI G, BARLETTA E, MUGNAI G, RUGGIERI S. Interaction of tumor cells with vascular endothelia: role of platelet-activating factor. Clin Exp Metastasis 2000; 18: 89-96. http: //dx.doi.org/10.1023/A: 1026548700247

[27] TRIPATHI YB, KANDALA JC, GUNTAKA RV, LIM RW, SHUKLA SD. Platelet-activating factor induces expression of early response genes c-fos and TIS- 1 in human epidermoid carcinoma A-431 cells. Life Sci. 1991; 49: 1761-1767. http: //dx.doi.org/10.1016/0024-3205(91)90319-7 
[28] MONTRUCCHIO G, LUPIA E, BATTAGLIA E, DEL SORBO L, BOCCELLINO M. Platelet-activating factor enhances vascular endothelial growth factor-induced endothelial cell motility and neoangiogenesis in a murine matrigel model. Arterioscl Thromb Vasc Biol 2000; 20: 80-88. http: //dx.doi. org/10.1161/01.ATV.20.1.80

[29] MONTRUCCHIO G, SAPINO A, BUSSOLATI B, GHISOLFI G, RIZEA-SAVU $S$ et al. Potential angiogenic role of platelet-activating factor in human breast cancer. Am J Pathol 1998; 153: 1589-1596. http: //dx.doi.org/10.1016/S00029440(10)65747-1

[30] SIROIS MG, EDELMAN ER. VEGF effect on vascular permeability is mediated by synthesis of platelet-activating factor. Am J Physiol. 1997; 272: H2746-H2756.

[31] DEO DD, AXELRAD TW, ROBERT EG, MARCHESELLI V, BAZAN NG et al. Phosphorylation of STAT-3 in response to basic fibroblast growth factor occurs through a mechanism involving platelet-activating factor, JAK-2, and Src in human umbilical vein endothelial cells. J Biol Chem 2002; 277: 21237-21245. http: //dx.doi.org/10.1074/jbc.M110955200

[32] ZHANG L, WANG D, JIANG W, EDWARDS D, QIU W et al. Activated networking of platelet activating factor receptor and FAK/STAT1 induces malignant potential in BRCA1-mutant at-risk ovarian epithelium. Reprod Biol Endocrinol 2010; 8: 74. http: //dx.doi.org/10.1186/1477-7827-8-74

[33] ISHII S, NAGASE T, TASHIRO F, IKUTA K, SATO $S$ et al. Bronchial hyperreactivity, increased endotoxin lethality and melanocytic tumorigenesis in transgenic mice overexpressing platelet-activating factor receptor. EMBO J 1997; 16: 133-142. http: //dx.doi.org/10.1093/emboj/16.1.133

[34] Biancone L, Cantaluppi V, Del Sorbo L, Russo S, TJOELKER LW et al. Platelet-activating factor inactivation by local expression of platelet-activating factor acetylhydrolase modifies tumor vascularization and growth. Clin Cancer Res 2003; 9: 4214-4220.

[35] MELNIKOVA VO, BALASUBRAMANIAN K, VILLARES GJ, DOBROFF AS, ZIGLER $M$ et al. Crosstalk between protease-activated receptor 1 and platelet activating factor receptor regulates melanoma cell adhesion molecule (MCAM/ MUC18) expression and melanoma metastasis. J Biol Chem 2009; 284: 28845-28855. http: //dx.doi.org/10.1074/jbc. M109.042150

[36] Denizot Y, Desplat V, Drouet M, Bertin F, Melloni B. Is there a role of platelet-activating factor in human lung cancer? Lung Cancer 2001; 33: 195-202. http://dx.doi.org/10.1016/S01695002(01)00197-0

[37] DENIZOT Y, GAINANT A, GUGLIELMI L, BOUVIER S, CUBERTAFOND P et al. Tissue concentrations of plateletactivating factor in colorectal carcinoma: inverse relationships with Dukes` stage of patients. Oncogene 2003; 22: 7222-7224. http: //dx.doi.org/10.1038/sj.onc. 1207032

[38] DENIZOT Y, CHIANEA T, LABROUSSE F, TRUFFINET V, DELAGE $M$ et al. Platelet-activating factor and human thyroid cancer. Eur J Endocrinol. 2005; 153: 31-40. http: //dx.doi. org/10.1530/eje.1.01947

[39] Pitton C, Lanson M, Besson P, et al. Presence of PAF-acether in human breast carcinoma: relation to axillary lymph node metastasis. J Natl Cancer Inst. 1989; 81: 1298-1302. http: //dx.doi.org/10.1093/jnci/81.17.1298

[40] APONTE M, JIANG W, LAKKIS M, LI MJ, EDWARDS D et al. Activation of platelet-activating factor receptor and pleiotropic effects on tyrosine phospho-EGFR/Src/FAK/paxillin in ovarian cancer. Cancer Res 2008; 68: 5839-5848. http://dx.doi. org/10.1158/0008-5472.CAN-07-5771

[41] KITAGAWA D, TAKETOMI A, KAYASHIMA H, KURODA Y, ITOH S et al. Expression of platelet-activating factor receptor: a novel prognosticator in patients with hepatocellular carcinoma following hepatectomy. Oncology 2007; 72: 381-387. http://dx.doi.org/10.1159/000113149

[42] Mathonnet M, Descottes B, Valleix D, Truffinet V, Labrousse $\mathrm{F}$ et al. Platelet-activating factor in cirrhotic liver and hepatocellular carcinoma. World J Gastroenterol 2006; 12: 2773-2778.

[43] ONUCHIC AC, MACHADO CML, SAITO RF, RIOS FJ, JANCAR S et al. Expression of PAFR as Part of a Prosurvival Response to Chemotherapy: A Novel Target for Combination Therapy in Melanoma. Mediators Inflamm 2012; 2012: 175408. http: //dx.doi.org/10.1155/2012/175408

[44] Lauren P. The two histological main types of gastric carcinoma: diffuse and so-called intestinal-type carcinoma. Act Pathol Microbiol Scand. 1965; 64: 31-49.

[45] SOBIN LH, WITTEKIND C. TNM Classification of Malignant Tumors, 5th edition, New York, Wiley-Liss, 1997.

[46] GIAGINIS C, DASKALOPOULOU SS, VGENOPOULOU S, SFINIADAKIS I, KOURAKLIS G et al. Heat Shock Protein-27, -60 and -90 expression in gastric cancer: association with clinicopathological variables and patient survival. BMC Gastroenterol. 2009; 9: 14. http: //dx.doi.org/10.1186/1471230X-9-14

[47] GIAGINIS CT, VGENOPOULOU S, TSOUROUFLIS GS, POLITI EN, KOURAKLIS GP et al. Expression and clinical significance of focal adhesion kinase in the two distinct histological types, intestinal and diffuse, of human gastric adenocarcinoma. Pathol Oncol Res 2009; 15: 173-181. http: //dx.doi.org/10.1007/s12253-008-9120-2

[48] GIAGINIS C, GIAGINI A, TSOUROUFLIS G, GATZIDOU E, AGAPITOS E et al. MCM-2 and MCM-5 expression in gastric adenocarcinoma: clinical significance and comparison with Ki-67 proliferative marker. Dig Dis Sci 2011; 56: 777-785. http: //dx.doi.org/10.1007/s10620-010-1348-5

[49] DENIZOT Y, DESCOTTES B, TRUFFINET V, VALLEIX D, LABROUSSE $\mathrm{F}$ et al. Platelet-activating factor and liver metastasis of colorectal cancer. Int J Cancer 2005; 113: 503-505. http: //dx.doi.org/10.1002/ijc.20585

[50] DENIZOT Y, DE ARMAS R, CAIRE F, POMMEPUY I, TRUFFINET V et al. Platelet-activating factor and human meningiomas. Neuropathol Appl Neurobiol 2006; 32: 674678. http: //dx.doi.org/10.1111/j.1365-2990.2006.00775.x

[51] Nigam S, MUller S, Benedetto C. Elevated plasma levels of platelet-activating factor $(\mathrm{PAF})$ in breast cancer patients with hypercalcemia. J Lipid Mediat. 1989; 1: 323-328.

[52] Cellai C, Laurenzana A, VANNUCCHI AM, CAPORALE R, PAGLIERANI $\mathrm{M}$ et al. Growth inhibition and differentiation of human breast cancer cells by the PAFR antagonist WEB2086. Br J Cancer 2006; 94: 1637-1642. 
[53] CELLAI C, LAURENZANA A, BIANCHI E, SDELCI S, MANFREDINI R et al. Mechanistic insight into WEB-2170-induced apoptosis in human acute myelogenous leukemia cells: the crucial role of PTEN. Exp Hematol 2009; 37: 1176-1185. http: //dx.doi.org/10.1016/j.exphem.2009.07.002

[54] Darst M, Al-Hassani M, Li T, Yi Q, TRAVERS JM et al. Augmentation of chemotherapy-induced cytokine production by expression of the platelet-activating factor receptor in a human epithelial carcinoma cell line. J Immunol 2004; 172: 6330-6335.
[55] SEO SK, KO HM, KIM HA, CHOI JH, JUN PARK S et al. Platelet-activating factor induces up-regulation of antiapoptotic factors in a melanoma cell line through nuclear factor- $\mathrm{kB}$ activation. Cancer Res 2006; 66: 4681-4686. http: //dx.doi. org/10.1158/0008-5472.CAN-05-3186

[56] DE OLIVEIRA SI, ANDRADE LN, ONUCHIC AC, NONOGAKI S, FERNANDES PD et al. Platelet-activating factor receptor (PAF-R)-dependent pathways control tumor growth and tumor response to chemotherapy. BMC Cancer 2010; 10: 200. http: //dx.doi.org/10.1186/1471-2407-10-200 